\title{
Shared Anti-Idiotype-AB-S027
}

National Cancer Institute

\section{Source}

National Cancer Institute. Shared Anti-Idiotype-AB-S027. NCI Thesaurus. Code C29434.

A monoclonal antibody directed ag ainst a specific tumor-associated antigen (TAA).

( $\mathrm{NCl04)}$ 